\title{
Insights into milk-clotting activity of latex peptidases from Calotropis procera and Cryptostegia grandiflora
}

\author{
Cleverson D.T. Freitas a,*, Hugo B. Leite a , João P.B. Oliveira a , Jackson L. Amaral a , Antônio S. Egito ${ }^{\text {b }}$, \\ Sandra Vairo-Cavalli ${ }^{\mathrm{c}}$, Marina D.P. Lobo ${ }^{\mathrm{d}}$, Ana C.O. Monteiro-Moreira ${ }^{\mathrm{d}}$, Márcio V. Ramos ${ }^{\mathrm{a}}$ \\ a Department of Biochemistry and Molecular Biology, Federal University of Ceara, Campus do Pici, Cx. Postal 6033, Fortaleza, CEP 60451-970, Ceara, Brazil \\ ${ }^{\mathrm{b}}$ Brazilian Agricultural Research Corporation, Embrapa Goats and Sheep, Estrada Sobral Groaíras km 4, Sobral, Ceara, Brazil \\ c Department of Biological Sciences, Faculty of Exact Sciences, Plant Proteins Research Centre (CIProVe), National University of La Plata, La Plata, Argentina \\ d NUBEX - Núcleo de Biologia Experimental, Centro de Ciências da Saúde, Universidade de Fortaleza-UNIFOR, Fortaleza, CE, Brazil
}

\section{A R T I C L E I N F O}

\section{Article history:}

Received 18 April 2016

Received in revised form 17 June 2016

Accepted 20 June 2016

Available online 22 June 2016

\section{Keywords:}

Casein

Chymosin

Himatanthus drasticus

Plumeria rubra

Papain-like peptidase

Rennet

\begin{abstract}
A B S T R A C T
Latex fractions from Calotropis procera, Cryptostegia grandiflora, Plumeria rubra, and Himatanthus drasticus were assayed in order to prospect for new plant peptidases with milk-clotting activities, for use as rennet alternatives. Only C. procera and C. grandiflora latex fractions exhibited proteolytic and milk-clotting activities, which were not affected by high concentrations of $\mathrm{NaCl}$ and $\mathrm{CaCl}_{2}$. However, pre-incubation of both samples at $75^{\circ} \mathrm{C}$ for $10 \mathrm{~min}$ eliminated completely their activities. Both proteolytic fractions were able to hydrolyze k-casein and to produce peptides of $16 \mathrm{kDa}$, a similar SDS-PAGE profile to commercial chymosin. RP-HPLC and mass spectrometry analyses of the k-casein peptides showed that the peptidases from C. procera or C. grandiflora hydrolyzed k-casein similar to commercial chymosin. The cheeses made with both latex peptidases exhibited yields, dry masses, and soluble proteins similar to cheeses prepared with commercial chymosin. In conclusion, C. procera and C. grandiflora latex peptidases with the ability to coagulate milk can be used as alternatives to commercial animal chymosin in the cheese manufacturing process.
\end{abstract}

(C) 2016 Elsevier Ltd. All rights reserved.

\section{Introduction}

Enzymes are among the most studied molecules in industry, because they have several biotechnological and biomedical applications (González-Rábade, Badillo-Corona, Aranda-Barradas, \& OliverSalvador, 2011). In 2009, the estimated value of the world market for these proteins was $\$ 220$ billion (Bhunia, Basak, \& Dey, 2012). Among all enzymes, peptidases represent around $60 \%$ of all of this market (González-Rábade et al., 2011; Ningthoujam, Kshetri, Sanasam, \& Nimaichand, 2009). In the food industry, the use of peptidases can confer new chemical, physical, and biological properties to protein-hydrolyzed, which can improve or exhibit new nutritional characteristics, delay deterioration, decrease allergenicity, change solubility, texture, taste, and smell, and also destroy toxic or inhibitory proteins (Tavano, 2013).

Animal peptidases with milk-clotting activities are the major enzymes used in cheesemaking. The most extensively used peptidase is

\footnotetext{
* Corresponding author.

E-mail address: cleversondiniz@hotmail.com (C.D.T. Freitas).
}

chymosin (EC 3.4.23.4), which is responsible for specific cleavage between bovine k-casein Phe $_{105}-\mathrm{Met}_{106}$ bond, resulting in the disruption of casein micelles and milk coagulation (Egito et al., 2007). Besides peptidase, another important parameter for the gelation of milk is the temperature. In general, coagulants can hydrolyse the casein at different temperatures; however, the milk does not clot at temperatures below $18{ }^{\circ} \mathrm{C}$ (Esteves, Lucey, Hyslop, \& Pires, 2003).

Since the global production volumes of cheese are increasing, peptidases with milk-clotting activity have also been obtained from other animals besides fungi, bacteria and plants. Furthermore, some plant peptidases with milk-clotting activity have also been proposed as rennet substitutes because the use of animal coagulants can be limited for religious (Judaism and Islam) and/or dietary (vegetarianism) reasons (Jacob, Jaros, \& Rohm, 2011; Shah, Mir, \& Paray, 2014).

Latex has been described as a fluid of milky aspect found in $>20,000$ plant species (Lewinsohn, 1991). Certainly, among all latex proteins, the peptidases are the most abundant and studied. Papain, isolated from Carica papaya latex, is the best known (Konno, 2011). Biotechnological applications of latex peptidases are numerous, such as in medicine: plasma-clotting (Viana et al., 2013), anti-cancer, antihelminthic, and anti-inflammatory activities (Salas, Gomes, Hernandez, \& Lopes, 
2008); in agriculture: defense against insects and fungi (Konno et al. 2004; Ramos et al., 2014); in the food industry: tenderization of meat (Rawdkuen, Jaimakreu, \& Benjakul, 2013) and milk-clotting activities (Badgujar \& Mahajan, 2014).

Here, the milk-clotting activity of latex cysteine peptidases from different species is reported about. The effects of peptidase concentration, $\mathrm{NaCl}, \mathrm{CaCl}_{2}$, and temperature on the milk-clotting activity are described, as well as the specificity on the hydrolysis of $\alpha, \beta$ and k-caseins. Two new cheeses were formulated, manufactured and partially characterized. The results presented here show the possible application of latex cysteine peptidases as alternatives to chymosin for the production of new cheeses with new flavors, and textures.

\section{Material and methods}

\subsection{Chemicals and reagents}

Azocasein, k-casein, papain, L-cysteine, Freund's complete and incomplete adjuvant, goat anti-rabbit IgG conjugated with alkaline phosphatase, and $p$-nitrophenyl phosphate disodium were purchased from Sigma-Aldrich (São Paulo, SP, Brazil). Dithiothreitol (DTT) and molecular mass markers were from GE HealthCare (São Paulo, SP, Brazil). Commercial chymosins (Coalhopar ${ }^{\circledR}$ and Halamix ${ }^{\circledR}$ ) were obtained at local markets (Fortaleza, CE, Brazil). All other chemicals were obtained from commercial sources and were of analytical grade.

\subsection{Plant material}

Peptidases from the latex fluids of Calotropis procera, Cryptostegia grandiflora, Plumeria rubra and Himatanthus drasticus were obtained as described by Freitas et al. (2007, 2010). The latex fluids were collected from non-cultivated healthy plants growing around Fortaleza-CE, Brazil. The peptidases from the latex of $C$. papaya green fruits was obtained as described by Teixeira, Ribeiro, Gomes, Lopes, and Salas (2008). The soluble proteins were quantified as described by Bradford (1976).

\subsection{Protein profile and proteolytic activity}

The protein profiles of all studied latex fractions were performed by SDS-PAGE as described by Freitas et al. (2007, 2010). The total proteolytic activities were determined using azocasein as a non-specific substrate and by zymogram containing $0.1 \%$ gelatin (Freitas et al., 2007, 2010). In the colorimetric assays, the reaction mixtures were constituted of different doses $(20,30,40,50,60,70,80,90$, and $100 \mu \mathrm{g})$ of latex proteins dissolved in $300 \mu \mathrm{L}$ of $50 \mathrm{mM}$ Tris- $\mathrm{HCl}$ buffer ( $\mathrm{pH}$ 6.5) containing $1 \mathrm{mM}$ DTT and $200 \mu \mathrm{L}$ of $1 \%$ azocasein. One unit of specific proteolytic activity (SPA) was defined as the amount of enzyme $(\mathrm{mg}$ ) required to produce an absorbance change of one unit per minute under the assay conditions. The effect of different reducing agents on proteolytic activities test was performed by pre-incubating each proteolytic fraction $\left(10 \mathrm{~min}\right.$ at $\left.25^{\circ} \mathrm{C}\right)$ with different concentrations of the reducing agents DTT, L-cysteine, and ascorbic acid (0-3 mM), as described above.

\subsection{Autolysis assays}

The proteolytic fractions of $C$. procera and C. grandiflora $(2 \mathrm{mg} / \mathrm{mL}$ in $50 \mathrm{mM}$ Tris- $\mathrm{HCl} \mathrm{pH} \mathrm{6.5,} \mathrm{containing} 1 \mathrm{mM}$ L-cysteine) were incubated at $37^{\circ} \mathrm{C}$ for $30 \mathrm{~min}, 1,4,8,24$, and $48 \mathrm{~h}$. Aliquots $(10 \mu \mathrm{L})$ of each time were used for determination of residual proteolytic activities (as described in Section 2.3) and the protein autolysis was achieved by SDS-PAGE, as described by Laemmli (1970).

\subsection{Milk-clotting activity}

The milk-clotting activity of the latex peptidases was assayed as described by Arima, Yu, and Iwasaki (1970). Different doses (20, 30, 40, 50,
$60,70,80,90$, and $100 \mu \mathrm{g}$ ) of the proteolytic fractions were dissolved in $200 \mu \mathrm{L}$ of $50 \mathrm{mM}$ Tris- $\mathrm{HCl}$ buffer (pH 6.5) containing $1 \mathrm{mM}$ L-cysteine and mixed with $2 \mathrm{~mL}$ of $10 \%$ skimmed milk in $10 \mathrm{mM} \mathrm{CaCl}_{2}$ at pH 6.5. Brazilian commercial chymosins (Coalhopar ${ }^{\circledR}$ and Halamix ${ }^{\circledR}$ ) were used as positive controls, as described by suppliers.

Clotting time was recorded when discrete particles were visible in the milk. One specific milk-clotting activity (SMCA) was defined as the amount of enzyme $(\mathrm{mg})$ that clotted $10 \mathrm{~mL}$ of milk within $40 \mathrm{~min}$ (Ahmed, Babiker, \& Mori, 2010), using the formula:

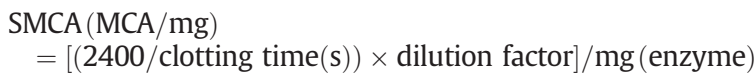

The effect of different temperatures $\left(37,45,55,65\right.$, and $75^{\circ} \mathrm{C}$ for 10 min), concentrations of $\mathrm{NaCl}$, and $\mathrm{CaCl}_{2}(10,50,100,200,500$, and $1000 \mathrm{mM}$ ) on the milk-clotting activity of the latex peptidases were also determined, as described above.

\subsection{Casein hydrolysis analysis}

\subsubsection{Preparation of bovine whole casein}

Whole casein was obtained by isoelectric precipitation as described by Egito et al. (2007), with slight modifications. Pasteurized bovine milk obtained from the local market was skimmed by centrifugation $\left(2100 \times \mathrm{g}\right.$ at $30^{\circ} \mathrm{C}$ for $\left.30 \mathrm{~min}\right)$. The supernatant was acidified up to $\mathrm{pH} 4.6$ with $\mathrm{HCl}$, centrifuged in the conditions described above, and the precipitate (casein fraction) was washed twice with distilled water, and centrifuged again. The casein fraction was dialyzed against distilled water at $8{ }^{\circ} \mathrm{C}$ for two days using a dialysis membrane with a cut off of $8000 \mathrm{Da}$ and then freeze-dried.

\subsubsection{Analysis of casein hydrolysis by SDS-PAGE}

Hydrolysis of the whole casein fraction ( $\alpha-, \beta-$, and k-caseins) and purified k-casein were performed as described by Ahmed et al. (2010), with slight modifications. The reaction mixtures were constituted of $50 \mu \mathrm{L}$ proteolytic fractions $(0.1 \mathrm{mg} / \mathrm{mL}$, dissolved in $50 \mathrm{mM}$ Tris$\mathrm{HCl}$ buffer pH 6.5 containing $1 \mathrm{mM} \mathrm{L-cysteine)} \mathrm{and} 450 \mu \mathrm{L}$ of whole casein fraction or purified k-casein $(10 \mathrm{mg} / \mathrm{mL})$. After 1, 5, 10, 15, 20 , 25 , and $30 \mathrm{~min}$ at $37^{\circ} \mathrm{C}$, an aliquot of $50 \mu \mathrm{L}$ of each reaction was mixed with the Tris- $\mathrm{HCl}$ buffer (pH 6.8), containing $0.1 \% \mathrm{SDS}$ and $5 \%$ mercaptoethanol, and boiled at $100^{\circ} \mathrm{C}$ for $5 \mathrm{~min}$. Samples were applied on a $15 \%$ SDS-PAGE $(8 \times 8 \mathrm{~cm})$, as described by Laemmli (1970). Identical assays were performed using commercial chymosin (Coalhopar ${ }^{\circledR}$ ) as the control.

\subsubsection{Analysis of $k$-casein hydrolysis by RP-HPLC and mass spectrometry}

The specific hydrolysis of the k-casein by latex peptidases of $C$. procera, C. grandiflora, and commercial chymosin (Coalhopar $\left.{ }^{\circledR}\right)$ were determined by reversed-phase high performance liquid chromatography (RP-HPLC) and mass spectrometry. After hydrolysis of the k-casein by peptidases (described in Section 2.6.2.), aliquots of each reaction $(500 \mu \mathrm{L})$ were centrifuged at $10000 \times g$ for $10 \mathrm{~min}$ at $10{ }^{\circ} \mathrm{C}$ and filtered through $0.22 \mu \mathrm{m}$ filters. Volumes of $50 \mu \mathrm{L}$ were loaded onto the $C_{2} C_{18}$ column ( $\mu$ RPC $C_{2} C_{18}$ ST, bed length $100 \mathrm{~mm}$, i.d. $4.6 \mathrm{~mm}, 3 \mu \mathrm{m}$ particle size, $12 \mathrm{~nm}$ porosity, Amersham Bioscience), coupled to a HPLC Jasco CO-2060 Plus. The peptides were eluted using a linear gradient from $5 \%$ to $40 \%$ acetronitrile for $30 \mathrm{~min}$, containing $0.1 \%$ trifluoroacetic acid (TFA), at $0.5 \mathrm{~mL} / \mathrm{min}$ flow rate. Proteins were detected at $230 \mathrm{~nm}$.

In another assay, the k-casein peptides were separated by $15 \%$ SDSPAGE $(8 \times 8 \mathrm{~cm})$. The $16 \mathrm{kDa}$ peptides (corresponding to para-k-casein peptide) were excised from the gels and electro-eluted using an electroeluter Model 422 (Bio-Rad Laboratories, Brazil) at $200 \mathrm{~V}$ for $3 \mathrm{~h}$ at $25^{\circ} \mathrm{C}$, following the manufacturer's instructions. The peptides (16 kDa) were dialyzed against distilled water (using membranes with a cut-off of $3 \mathrm{kDa}$ ) and freeze-dried. The molecular masses of the para-k-casein peptides were determined using a Synapt HDMS mass spectrometer 
(Waters, Manchester, UK) coupled to a 2D NanoUPLC-ESI system as describes by Freitas et al. (2015).

\section{7. "Coalho" cheese manufacture}

For the activation of the cysteine peptidases, the proteolytic fractions from C. procera and C. grandiflora (in different concentrations), were dissolved in $10 \mathrm{~mL}$ of distilled water (containing $1 \mathrm{mM} \mathrm{L}$-cysteine) and incubated for $5 \mathrm{~min}$ at $25^{\circ} \mathrm{C}$. Separately, the proteolytic fractions were added to $500 \mathrm{~mL}$ of pasteurized bovine milk containing $50 \mathrm{mM}$ of $\mathrm{CaCl}_{2}$. After $30-40 \mathrm{~min}$ at $25{ }^{\circ} \mathrm{C}$, the coagulum formed was manually cut into cubes, making two phases: curd and whey. Part of the whey $(250 \mathrm{~mL})$ was removed, heated at $80{ }^{\circ} \mathrm{C}$ for $10 \mathrm{~min}$, and added again to the curd. After constant stirring for $10 \mathrm{~min}$, the whey was totally drained from the curd by pressurizing for $12 \mathrm{~h}$ at $25^{\circ} \mathrm{C}$ using a handmade machine. The pressed materials represented the "Coalho" cheeses.

\subsection{Proteolytic activity in cheeses}

Cheeses manufactured ( $1 \mathrm{~g}$ ) using $C$. procera and C. grandiflora peptidases were lyophilized and proteins were extracted with $10 \mathrm{~mL}$ of $50 \mathrm{mM}$ Tris- $\mathrm{HCl}$ buffer ( $\mathrm{pH} \mathrm{6.5)} \mathrm{for} 10 \mathrm{~min}$ at $8{ }^{\circ} \mathrm{C}$. The suspension was centrifuged at $5000 \times \mathrm{g}$ for $10 \mathrm{~min}$ at $5{ }^{\circ} \mathrm{C}$, and different aliquots of the supernatants $(50,100$, and $200 \mu \mathrm{L})$ were incubated with $1 \%$ azocasein. The proteolytic activity was determined as described in Section 2.3. Identical assays were performed with cheeses manufactured using commercial chymosin (Coalhopar $\left.{ }^{\circledR}\right)$. Extracts obtained in the same way were used to detect residual latex proteins in cheeses by ELISA assays.

\subsection{Detection of latex proteins in cheeses}

Immunological assays were performed to detect the remaining latex proteins in the cheeses. C. procera (CpLP) and C. grandiflora (CgLP) Latex Peptidases ( $1 \mathrm{mg}$ ) were dissolved in a $0.5 \mathrm{~mL}$ saline solution, and mixed with $0.5 \mathrm{~mL}$ of Freund's complete adjuvant as described by Freitas et al. (2015). Separately, each suspension (1 mL) was injected intramuscularly into two adult New Zealand white male rabbits followed by booster injections (21, 35, and 42 days) of the same dose with Freund's incomplete adjuvant. Serum samples were collected weekly from day 21, and mixed as a pool. The anti-CpLP and anti-CgLP IgG pools were maintained at $-20{ }^{\circ} \mathrm{C}$ until use. Experimental procedures and animal handling were performed in accordance with the guidelines approved by the Institutional Animal Ethics Committee of the Federal University of Ceara, Brazil.

ELISA assays were performed using anti-CpLP and anti-CgLP IgG as the primary antibodies (1:10000 dilution) and goat anti-rabbit IgG conjugated to alkaline phosphatase (1:5000 dilution) as the secondary antibodies. Experiments were developed in 96-well microplates using the substrate $p$-nitrophenyl phosphate disodium $(5 \mathrm{mg} / \mathrm{mL})$. Initially, each well of the microplates was filled with $150 \mu \mathrm{L}$ of the cheese protein extracts (obtained as described in Section 2.8). After incubation at $25^{\circ} \mathrm{C}$ for $12 \mathrm{~h}$, the wells were blocked with $200 \mu \mathrm{L}$ of BSA $(5 \mathrm{mg} / \mathrm{mL})$ for $2 \mathrm{~h}$ at $25{ }^{\circ} \mathrm{C}$, and washed with $150 \mu \mathrm{L}$ of PBS buffer. Primary antibodies $(150 \mu \mathrm{L})$ were added to each well and, after $2 \mathrm{~h}$ at $25^{\circ} \mathrm{C}$, the plates were washed again with $150 \mu \mathrm{L}$ of PBS buffer. Secondary antibodies were added $(150 \mu \mathrm{L})$, incubated for $2 \mathrm{~h}$ at $25^{\circ} \mathrm{C}$ and washed with $150 \mu \mathrm{L}$ of PBS buffer. The substrate was then added, and incubated for $1 \mathrm{~h}$ in the dark. The reaction was stopped by the addition of $3 \mathrm{M}$ $\mathrm{NaOH}(50 \mu \mathrm{L})$ and the reaction was quantified by absorbance at $405 \mathrm{~nm}$ using an automated microplate reader (ELx800 Absorbance Microplate Reader, BioTek Customer Care).

\subsection{Statistical analyses}

The statistical analyses were performed using GraphPad Prism Software (Version 5.0, San Diego, CA), obtained by variance analysis (ANOVA, $\mathrm{n}=3$ ), followed by Tukey's test for multiples comparison. $\mathrm{P}<0.05$ was considered as statistically significant.

\section{Results and discussion}

\subsection{Protein profile and proteolytic activity}

Protein profiles of all studied latex fractions are shown in Supplementary Fig. 1A. The results obtained were in concordance with those originally described by Freitas et al. (2007, 2010), where the latex fractions were also characterized by two dimensional gel electrophoresis and mass spectrometry. The latex fractions exhibited protein profiles with molecular masses ranging from $12 \mathrm{kDa}$ up to $100 \mathrm{kDa}$ (Supplementary Fig. 1A). These dissimilarities in protein contents of latex fluids were recently discussed by Freitas et al. (2016), where the protein profile of the Thevetia peruviana latex was studied by two dimensional gel electrophoresis. The most interesting is that independent of qualitative or quantitative protein content, the latex fluids, in general, exhibit proteolytic activity (Domsalla \& Melzing, 2008). The latex fractions of $C$. procera and $C$. grandiflora exhibited high proteolytic activity in vitro, similar to $C$. papaya latex fraction and papain (cysteine peptidases used as controls) (Supplementary Fig. 2A). These results were confirmed by zymogram, where, at least, three different bands with intense proteolytic activity were detected in each sample (Supplementary Fig. 1B). The proteolytic activity in vitro of the P. rubra latex fraction was negligible (Supplementary Fig. 2A), and the zymogram showed the presence of two bands with proteolytic activity (Supplementary Fig. 1B). The latex fraction of $H$. drasticus did not exhibit proteolytic activity at all (in vitro and by zymogram). Latex fluids have been described as rich sources of cysteine and serine peptidases (Domsalla \& Melzing, 2008). In the latex fluids of C. papaya (Azarkan, El Moussaoui, van Wuytswinkel, Dehon, \& Looze, 2003), C. procera and C. grandiflora only cysteine peptidases have been described, whereas in $P$. rubra latex there is a mixture of serine and cysteine peptidases (Freitas et al., 2010; Ramos, Araújo, Jucá, Monteiro-Moreira, \& Vasconcelos, 2013).

The presence of cysteine peptidases was confirmed by proteolytic enzyme activation of the $C$. procera latex fraction with the reducing agents dithiothreitol (DTT) and L-cysteine (Supplementary Fig.2B). In another study, Oseni and Ekperigin (2013) showed the activation effect of L-cysteine on proteolytic enzymes of $C$. procera latex. Dubey and Jagannadham (2003) showed also that procerain, a cysteine peptidase from $C$. procera latex, was activated with DTT $(2-3 \mathrm{mM})$, and at high concentrations of DTT (10 mM) its activity was loss, which may be due to reduction of internal disulfide bonds of the enzyme. Ascorbic acid was not able to activate the peptidases from $C$. procera (Supplementary Fig. 2B). The $C$. grandiflora and $C$. papaya latex peptidases, and purified papain were activated by DTT and L-cysteine, similar to $C$. procera peptidases. $P$. rubra latex peptidases were not activated by any reducing agent assayed (data not shown). Because L-cysteine is a nontoxic essential amino acid and exhibited activity similar to DTT, it was used further in all milk-clotting assays. Therefore, besides its action as an activator, L-cysteine can be used as a nutritional supplement in cheeses manufactured with latex cysteine peptidases. So far, the use of L-cysteine in cheese is unique, which open new perspectives in the cheese market.

\subsection{Milk-clotting activity}

Peptidases from $C$. procera and $C$. grandiflora exhibited dose-dependent milk-clotting activity up to $50-60 \mu \mathrm{g}$ to $2 \mathrm{~mL}$ of milk (Fig. 1A). These results were very similar to $C$. papaya, and purified papain, used 

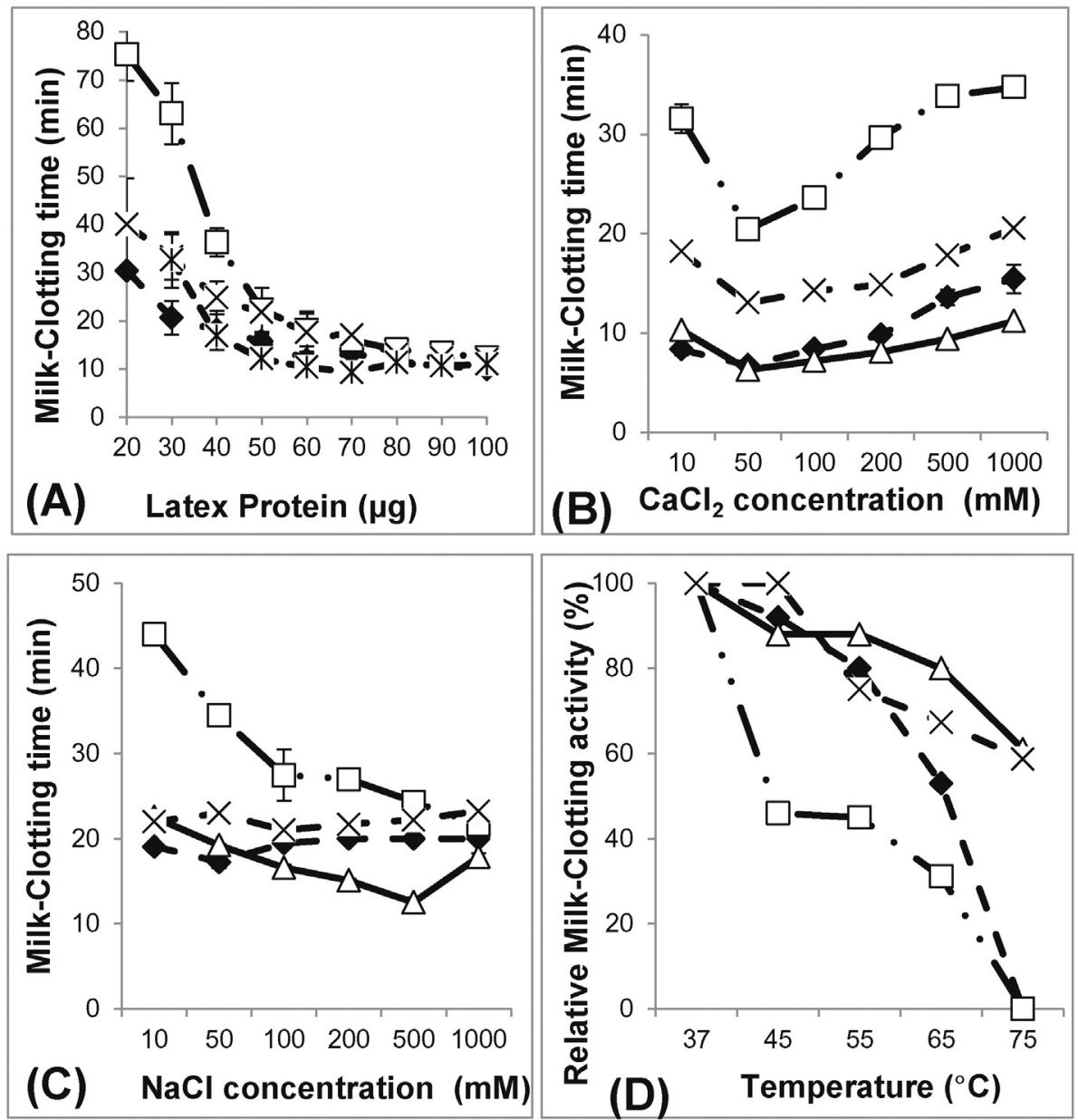

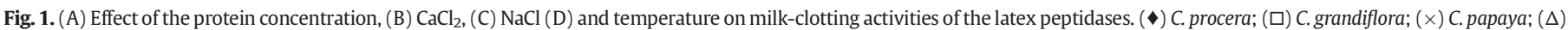

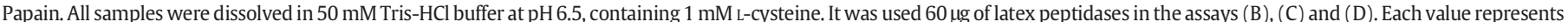
the mean of three independent experiments and error bars indicate standard error of the mean.

as control cysteine peptidases. Doses higher than $60 \mu \mathrm{g}$ were not effective to improve substantially the milk-clotting activity. The proteolytic activities of the latex peptidases exhibited a similar kinetic, with maximum activity using $60 \mu \mathrm{g}$ (Supplementary Fig. 2A). Therefore, the dose used of each latex fraction in all further assays was $60 \mu \mathrm{g}$. Our data were similar to those showed by Silva and Malcata (2005), which correlated the clotting time with the peptidase concentration of Cynara cardunculus. No difference was observed in milk-clotting activity when using whole or skimmed milk (data not shown). Interestingly, the overall aspects of the formed curds were different between some enzymatic preparations assayed, which can indicate, at least in part, the specific activity of each peptidase (Fig. 2). C. papaya and purified papain (cysteine peptidase controls) made curds similar to Brazilian commercial chymosins (Coalhopar ${ }^{\circledR}$ and Halamix ${ }^{\circledR}$ ). Likewise, proteolytic extracts of Moringa oleifera and Solanum dubium, and a purified cysteine peptidase of Euphorbia microsciadia coagulated the skimmed milk and formed a white and firm curd (Ahmed et al., 2010; Pontual et al., 2012; Rezanejad, Karbalaei-Heidari, Rezaei, \& Yousefi, 2015). P. rubra and $H$. drausticus were not able to coagulate the milk even at the highest tested dosage ( $100 \mu \mathrm{g})$.

Specific milk-clotting (SMCA) and proteolytic activities (SPA) of the latex fractions, papain and two commercial chymosins (Halamix ${ }^{\circledR}$ and Coalhopar ${ }^{\circledR}$ ) are shown in Table 1 . The ratio of milk-clotting activity to proteolytic activity (SMCA/SPA) is an important indicator used to determine the potential of the peptidase as coagulants for cheese manufacture (Arima et al., 1970). This means that good coagulants present high milk-clotting activity and low proteolytic activity, resulting in less hydrolysis of the caseins. Among all samples, the best results were obtained for papain (1880.0 SMCA/SPA) and C. procera (1788.3 SMCA/ SPA) latex peptidases. Similar results were obtained with a ginger rhizome cysteine peptidase (1653.0 SMCA/SPA) (Hashim, Mingsheng,

CpLP Control CgLP Control CapLP Control Halamix Control
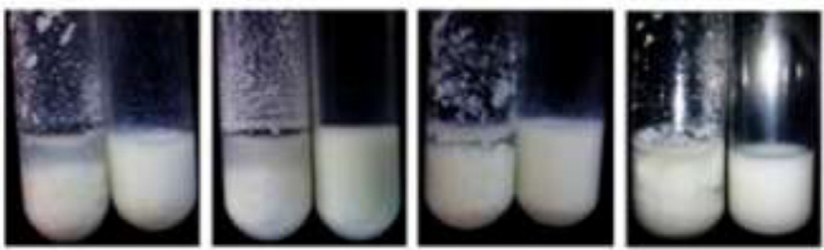

Papain Control

HdLP Contro

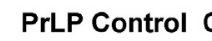

Coalhopar Control
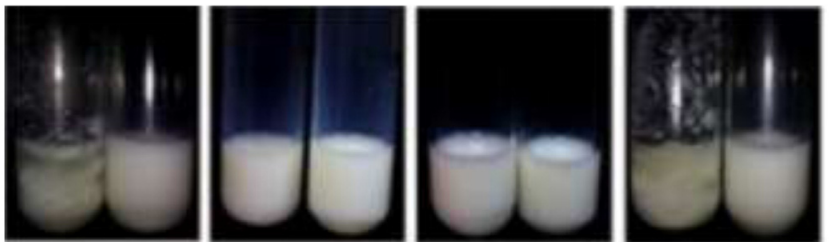

Fig. 2. Overall aspect of the milk-clotting activities of the latex peptidases and Brazilian commercial chymosins (Coalhopar ${ }^{\circledR}$ and Halamix $\left.{ }^{\circledR}\right)$. The samples $(60 \mu \mathrm{g}$ ) were dissolved in $50 \mathrm{mM}$ Tris- $\mathrm{HCl}$ buffer ( $\mathrm{pH}$ 6.5), containing $1 \mathrm{mM}$ L-cysteine and added to $2 \mathrm{~mL}$ of skimmed milk (10\%). The photos were taken after $30 \mathrm{~min}$ at $25^{\circ} \mathrm{C}$. CpLP: $\mathrm{C}$. procera; CgLP: C. grandiflora; PrLP: P. rubra; CapLP: C. papaya; HdLP: H. drasticus. Control: Tris- $\mathrm{HCl}$ buffer. 
Table 1

Milk-clotting and proteolytic activities of the latex peptidases and commercial coagulants.

\begin{tabular}{llll}
\hline Enzymes & SMCA $^{\mathrm{a}}(\mathrm{AU} / \mathrm{mg})$ & SPA $^{\mathrm{b}}(\mathrm{AU} / \mathrm{mg})$ & Ratio $(\mathrm{SMCA} / \mathrm{SPA})$ \\
\hline $\begin{array}{l}\text { Latex peptidases } \\
\text { Calotropis procera }\end{array}$ & $566.3 \pm 86.9$ & $0.31 \pm 0.04$ & 1788.3 \\
$\begin{array}{l}\text { Carica papaya } \\
\text { Cryptostegia grandiflora }\end{array}$ & $404.3 \pm 11.9$ & $0.29 \pm 0.02$ & 1359.6 \\
Himatantus drausticus & $\mathrm{Nd}^{*} \pm 10.6$ & $0.35 \pm 0.09$ & 1154.8 \\
Plumeria rubra & $\mathrm{Nd}^{*}$ & $\mathrm{Nd}^{*}$ & - \\
Purified peptidase & & $0.03 \pm 0.01$ & - \\
Papain & & & \\
& $720.7 \pm 47.3$ & $0.38 \pm 0.06$ & 1880.0 \\
Commercial rennets & & & \\
CoalhoPar rennet & $415.3 \pm 30.6$ & $0.24 \pm 0.04$ & 1730.4 \\
Halamix ${ }^{*}$ rennet & $226.3 \pm 41.2$ & $0.21 \pm 0.03$ & 1077.6 \\
\hline
\end{tabular}

Each value represents the mean of three independent experiments and error bars indicate standard error of the mean.

$\mathrm{Nd}^{*}=$ not detected at $\mathrm{pH} 6.5$.

a SMCA: specific milk-coagulating activity.

b SPA: specific proteolytic activity.

Iqbal, \& Xiaohong, 2011). Other plant cysteine peptidases such as those from kiwi fruit (Actinidin), E. microsciadia and Vasconcellea quercifolia latex also showed potential as milk-clotting agents (Grozdanovic, Burazer, \& Gavrovic-Jankulovic, 2013; Rezanejad et al., 2015; Torres et al., 2010).

The concentration of ions such as calcium and sodium represents an important element because both can be used during cheese manufacture and some milk-clotting enzymes can be inactivated by them. $\mathrm{CaCl}_{2}$ is usually added to milk to improve the milk coagulation. However, it is also documented that the addition of high concentrations of calcium chloride can reduce the $\mathrm{pH}$ of milk, resulting in a decreased aggregation rate and possible proteolytic inactivation (WolfschoonPombo, 1997). Therefore, the effect of $\mathrm{CaCl}_{2}$ concentrations on milkclotting activity of the latex peptidases was evaluated (Fig. 1B). All samples presented maximum milk-clotting activity at a final concentration of $50 \mathrm{mM} \mathrm{CaCl}_{2}$, a similar result found for other clotting plant enzymes (Bruno et al., 2010; Pontual et al., 2012). At higher concentrations of $\mathrm{CaCl}_{2}$ (100-1000 mM), there was a reduction in the milk-clotting activity, when compared with $50 \mathrm{mM} \mathrm{CaCl}_{2}$. However, even at $1 \mathrm{M} \mathrm{CaCl}_{2}$, the milk-clotting activity was similar to that displayed when using $10 \mathrm{mM}$ $\mathrm{CaCl}_{2}$ for all latex peptidases (Fig. 1B). These results were interesting because the addition of calcium chloride in milk was reported to increase milk-clotting time by calf rennet (Famelart, Le Graet, \& Raulot, 1999) and crude enzyme extracts of Withania sp. and S. dubium (Ahmed et al., 2010; Naz, Masud, \& Nawaz, 2009).

$\mathrm{NaCl}$ can be added to milk for many functions such as taste, stability of endogenous protein and syneresis of the curd. It also influences cheese ripening, principally through its effect on water activity (Guinee \& Fox, 2004). Besides, traditionally, in Domiati and Gibna cheeses, high concentrations of $\mathrm{NaCl}$ are added to milk to control the growth of microorganisms (Guinee \& Fox, 2004). The NaCl concentration increased the milk-clotting activity of $C$. grandiflora peptidases and papain. At the highest concentration assayed $(1 \mathrm{M} \mathrm{NaCl})$, the relative activity for C. grandiflora and papain were $152 \%$ and $122 \%$, respectively, when compared at $10 \mathrm{mM} \mathrm{NaCl}$ (100\%) (Fig. 1C). Similar results were exhibited by S. dubium seed peptidases, where $2 \mathrm{M} \mathrm{NaCl}$ was a powerful stimulator of the enzyme activity (Ahmed et al., 2010). On the other hand, the milk-clotting activity of $C$. procera peptidases did not change even at $1 \mathrm{M} \mathrm{NaCl}$ (Fig. 1C). These results reinforce again that latex peptidases from $C$. procera and $C$. grandiflora can be good candidates for cheese manufacture, because it is also known that $\mathrm{NaCl}$ can decrease the milk-clotting activity of plant coagulants (Guiama et al., 2010).

The milk-clotting activities of the latex peptidases of $C$. procera and $C$. grandiflora were maximum at $37^{\circ} \mathrm{C}$ and decreased $20 \%$ and $55 \%$, respectively after pre-heating at $55{ }^{\circ} \mathrm{C}$ for $10 \mathrm{~min}$ (Fig. 1D). Papain started its denaturation at $45-55{ }^{\circ} \mathrm{C}$, according to thermal denaturation studies that used differential scanning calorimetry and spectrophotometric methods (Sumner et al., 1993). Excluding C. papaya peptidases and papain, all samples studied here lost milk-clotting activities after preheating at $75{ }^{\circ} \mathrm{C}$ for $10 \mathrm{~min}$ (Fig. 1D). M. oleifera flower peptidases were also totally inactivated at $60-70{ }^{\circ} \mathrm{C}$ (Pontual et al., 2012). In contrast, milk-clotting enzymes from different plants such as Solanum esculentum, Solanum melongena and Solanum macrocarpon were stable proteins, remaining active after heating to $70{ }^{\circ} \mathrm{C}$ (Guiama et al., 2010) and a milk-clotting peptidase named religiosin B, purified from Ficus religiosa latex, showed milk-clotting activity at $60^{\circ} \mathrm{C}$ (Kumari, Sharma, \& Jagannadham, 2012). High thermal and pH stability are important biochemical properties used for the choice of enzymes to be used in several biotechnological applications. However, a coagulant with high $\mathrm{pH}$ and thermal stabilities can produce an extensive hydrolysis of the milk proteins, resulting in cheeses with undesirable flavors. A step used in the production of the "Coalho" cheese in Brazil is the removal of part of the whey from the curd and its heating up to $80^{\circ} \mathrm{C}$, and further addition to mixture to cook the curd. In this case, inactivation of the peptidases at $80^{\circ} \mathrm{C}$ can avoid an extensive hydrolysis of milk caseins during cheese maturation, which can modify properties of the cheese such as texture and taste.

\subsection{Autolysis}

In general, peptidases can undergo inactivation or autolysis, depending on several factors, including the storage time and temperature (Chen, Shun, Zhang, \& Gao, 2003). The proteolytic activity of the $C$. procera and C. grandiflora latex fractions remained stable (100\%) at $37^{\circ} \mathrm{C}$ for $8 \mathrm{~h}$ at $2 \mathrm{mg} / \mathrm{mL}$. Only after 24 and $48 \mathrm{~h}$, there was a considerable loss of activity (20-80\%), depending on the latex fraction (Supplementary Fig. 3A). Similarly, milk-clotting latex peptidases of Ficus carica were stable up to $24 \mathrm{~h}$ at $37^{\circ} \mathrm{C}$ (Zare et al., 2013). In contrast, a milkclotting cysteine peptidase of Euphorbia nivulia latex exhibited low stability, retaining only $20 \%$ of its residual activity after 10 min of incubation at $40{ }^{\circ} \mathrm{C}$ (Badgujar \& Mahajan, 2014). The autolysis of C. procera and $C$. grandiflora proteolytic fractions was evaluated by SDS-PAGE (Supplementary Fig. 3B). Both fractions did not exhibit changes in their protein contents (autodigestion) even after $48 \mathrm{~h}$ of incubation at $37^{\circ} \mathrm{C}$, reinforcing their high stabilities and potentials use in food industry.

\subsection{Casein hydrolysis by latex peptidases}

The degree of $\alpha-, \beta-$, and k-casein hydrolysis by latex peptidases was analyzed by SDS-PAGE (Supplementary Fig. 4). The latex peptidases from C. procera, C. grandiflora, and C. papaya exhibited unspecific hydrolysis on all caseins after 5 min of incubation. In contrast, the commercial coagulants (Coalhopar ${ }^{\circledR}$ and Halamix ${ }^{\circledR}$ ) were specific, cleaving only the k-casein electrophoretic band. Peptidases from P. rubra and $H$. drasticus were not able to cleave the caseins. In order to quantify the casein hydrolysis by peptidases, the gels were scanned and the densitometries of the casein bands were plotted as a percentage of the control residual casein (time 0 ). The densitograms revealed that $C$. procera peptidases $(\mathrm{CpLP})$ were more specific in k-casein hydrolysis than $C$. grandiflora (CgLP) and C. papaya (CapLP) peptidases (Fig. 3). Similar results were exhibited by $S$. dubium seed and Bromelia hieronymi fruit peptidases, which were able to hydrolyse the three casein components, but with a higher specificity to k-casein (Ahmed et al., 2010; Bruno et al., 2010).

The qualities of the cheese, which include taste, flavor and texture, can be reflected by the specific hydrolysis of the k-casein. Chymosin cleaves specifically between $\mathrm{Phe}_{105}$ and $\mathrm{Met}_{106}$ bond of the k-casein, producing the para-k-casein and glycomacropeptide (Egito et al., 2007). Therefore, assays were performed by incubating purified bovine k-casein with C. procera and $C$. grandiflora peptidases for different times. The action of commercial chymosin on k-casein produced two major 

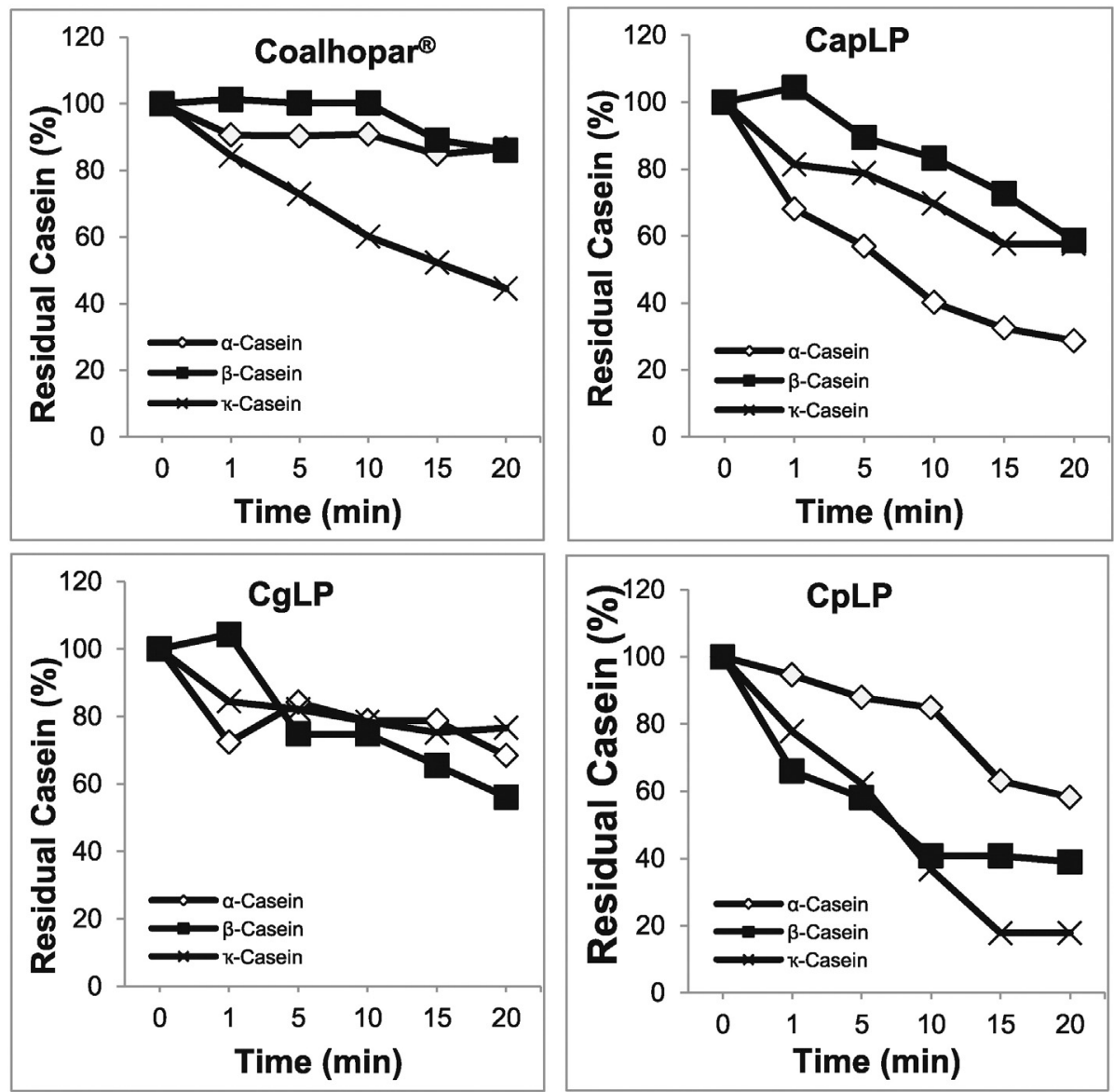

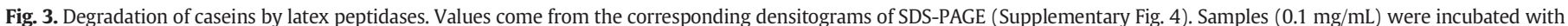
casein fractions $(10 \mathrm{mg} / \mathrm{mL})$ for different times at $37{ }^{\circ} \mathrm{C}$ and pH 6.5. CpLP: C. procera; CgLP: C. grandiflora; CapLP: C. papaya. Coalhopar ${ }^{\circledR}$ : commercial chymosin.

peaks, as seen in RP-HPLC analysis (Fig. 4). These two peaks probably correspond to para-k-casein and glycomacropeptide (Egito et al., 2007). Peaks, eluted in same position, were also observed after k-casein hydrolysis by $C$. procera or $C$. grandiflora peptidases, as early as 5 min (Fig. 4). These results suggested, at least in part, that both, $C$. procera

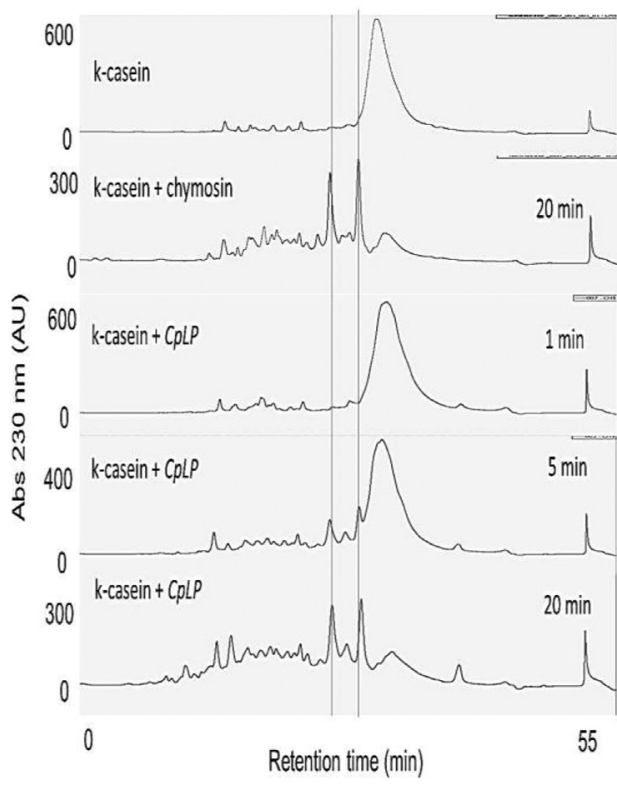

and $C$. grandiflora peptidases hydrolyse k-casein in same position that commercial animal coagulant (Coalhopar). In the same way, Cardosin $A$ and $B$, two aspartic peptidases from $C$. cardunculus, and sunflower peptidases hydrolyzed k-casein at the $\mathrm{Phe}_{105}-\mathrm{Met}_{106}$ bond, as does chymosin (Egito et al., 2007; Silva \& Malcata, 2005). It appears that

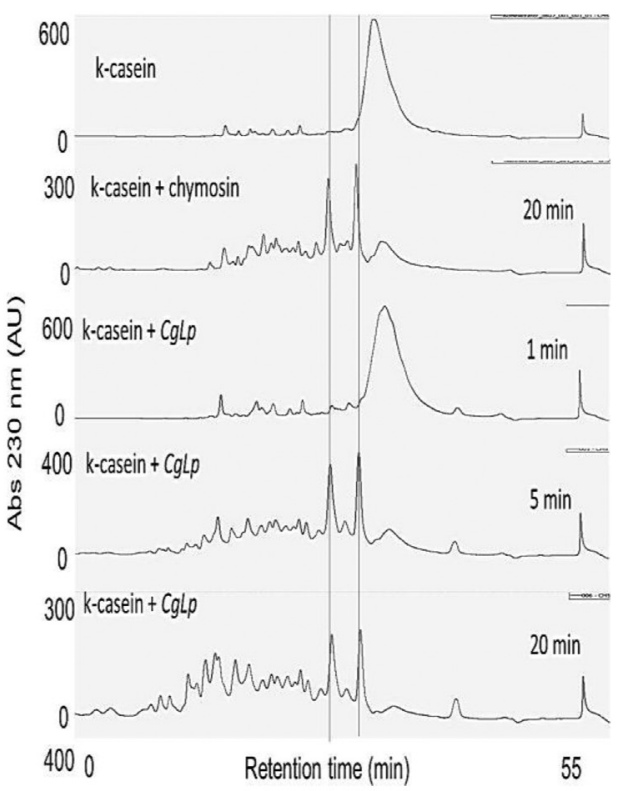

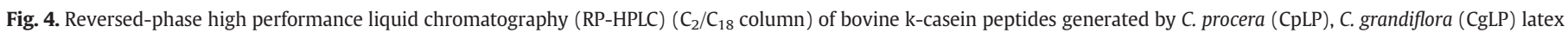
peptidases and commercial chymosin (Coalhopar ${ }^{\circledR}$ ) at $\mathrm{pH} 6.5,37^{\circ} \mathrm{C}$ for different times. 
other peptides, besides para-k-casein and glycomacropeptide, were produced with action of $C$. procera and $C$. grandiflora peptidases, indicating that latex peptidases can cleave k-casein in other sites (Fig. 4). This thinking was also supported by electrophoresis (Fig. 5). Milk-clotting peptidases belonging to albizia and ginger cleaved k-casein in other sites, such as $\mathrm{Lys}_{116}-\mathrm{Thr}_{117}, \mathrm{Ala}_{90}-\mathrm{Glu}_{91}$ and $\mathrm{His}_{102}-\mathrm{Leu}_{103}$, respectively (Egito et al., 2007; Huang, Chen, Luo, Guo, \& Ren, 2011). It has also been described that these slight differences in cleavage sites do not affect milk-clotting activity and taste of the cheeses (Hang et al., 2016).

The action of $C$. procera and $C$. grandiflora peptidases on k-casein was also performed by SDS-PAGE (Fig. 5). The reduction in intensity of thekcasein band by $C$. procera and $C$. grandiflora peptidases was accompanied by an increase in the intensity of a $16 \mathrm{kDa}$ peptide band, which probably corresponded to para-k-casein peptide (insert Fig. 5A). A similar protein band was observed when k-casein was hydrolyzed with the commercial chymosin (Coalhopar ${ }^{\circledR}$ ). In addition, the k-casein hydrolysis by $C$. procera peptidase also produced other peptides with molecular masses between 29 and $20 \mathrm{kDa}$, which was not observed when C. grandiflora and commercial chymosin were assayed (Fig. 5A). The para-k-casein peptides ( $16 \mathrm{kDa}$ bands) produced by action of the two latex peptidases and by commercial chymosin were excised from the SDS-PAGE gels, electro-eluted, and submitted to LC/ESI-MS analysis (Fig. 5B). The three $16 \mathrm{kDa}$ protein bands produced by action of $C$. procera and $C$. grandiflora peptidases and by commercial chymosin (Coalhopar) on k-casein exhibited molecular masses of $8602 \mathrm{Da}$ (Fig. 5B). Previous study reported para-k-casein with molecular mass of 12,270 Da when digested with purified chymosin (Egito et al., 2007). The lower para-k-casein observed here may be result of additional hydrolysis performed by the proteolytic activity of both, $C$. procera and $C$. grandiflora samples. Examining the protein content of commercial chymosin (Coalhopar) by MS/MS analysis after electrophoresis it was identified the peptidase trypsin, in addition of chymosin (data not shown). Thus, this contaminating activity could account for further hydrolysis of para-k-casein, resulting in the shorter peptide.

\subsection{Cheese manufacture and partial characterization}

Some characteristics of the cheeses made with C. procera and C. grandiflora peptidases are presented in Table 2 . The best results of coagulation time with $500 \mathrm{~mL}$ of milk were obtained with 9 and $40 \mathrm{mg}$ of the $C$. procera and C. grandiflora proteolytic fractions, respectively. The time of coagulation was between 7 and $17 \mathrm{~min}$ at $25^{\circ} \mathrm{C}$. In these concentrations, the yield, dry mass and soluble proteins' values and appearances of cheeses made with latex peptidases were similar to those prepared with commercial chymosin (Table 2 and Fig. 6). The complete sensory analysis of the two cheeses will be performed and described in a future work.

The cheeses made with latex peptidases did not show residual proteolytic activity, similar to cheeses manufactured with commercial chymosin (data not shown). This result was important because there will be a low or even no hydrolysis of the caseins during the cheese ripening process, avoiding possible changes in texture, taste, and flavor of the product. These results corroborated with those from Fig. 1D where $C$. procera and $C$. grandiflora peptidases were inactivated after heating at $75^{\circ} \mathrm{C}$ for $10 \mathrm{~min}$. During the manufacture of the "Coalho" cheeses, one step consists of the heating of the whey up to $80^{\circ} \mathrm{C}$ to cook the curd. Thus, in this step the latex peptidases can be inactivated. Llorente, Obregón, Avilés, Caffini, and Vairo-Cavalli (2014) showed that flower proteolytic extracts from Cynara scolymus coagulated the milk and made cheeses similar to those achieved with animal chymosin. However, they showed that the proteolytic fractions were active even during the cheese maturation for 45 days, with an accompanying bitter
(A)

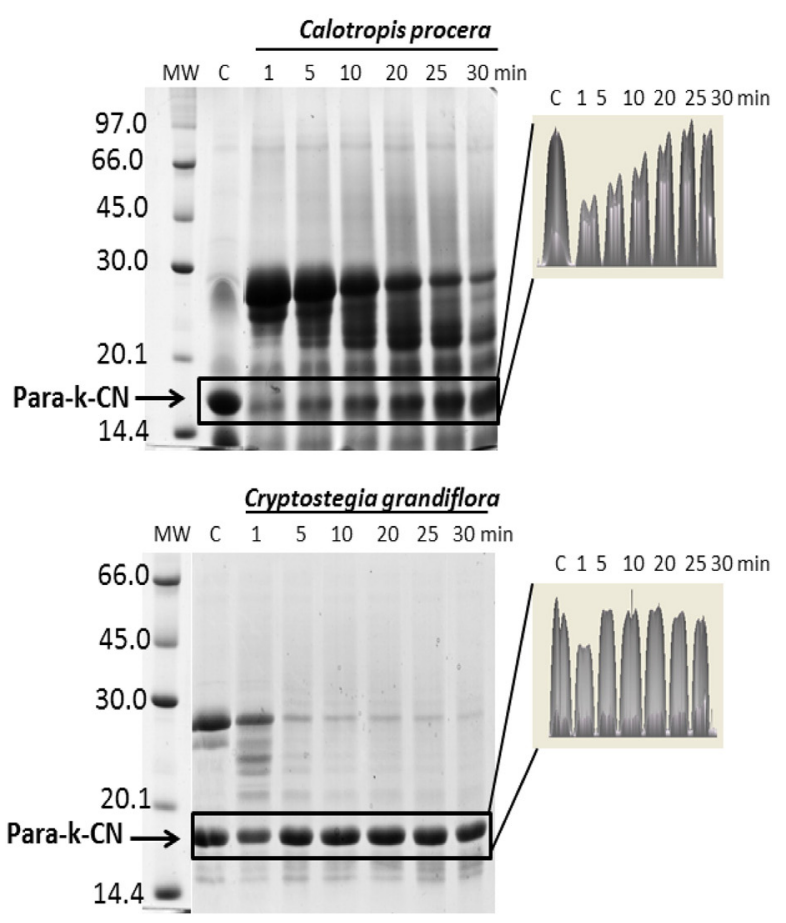

(B)

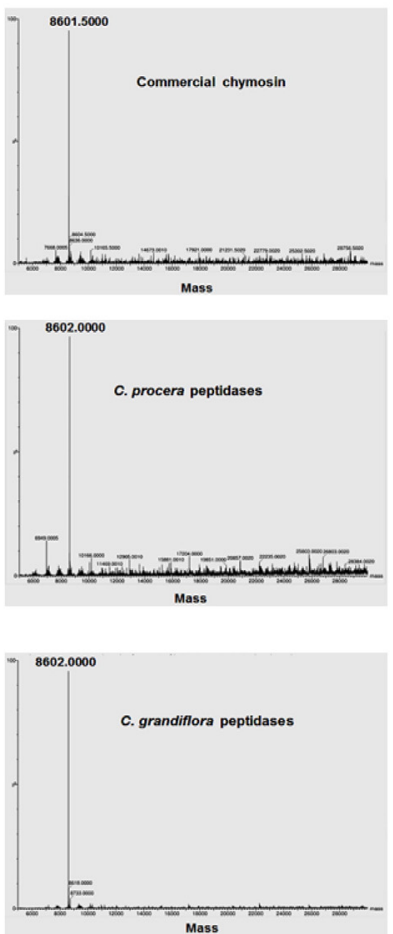

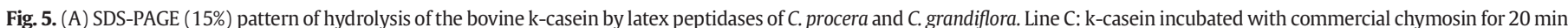

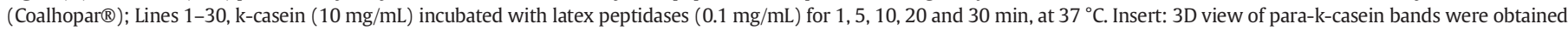

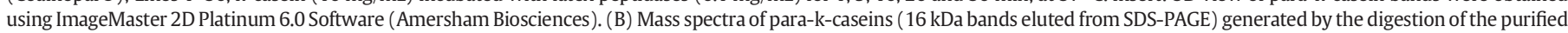
k-casein with commercial chymosin, C. procera and C. grandiflora peptidases. 
Table 2

Some characteristics of the cheeses manufactured with Calotropis procera and Cryptostegia grandiflora peptidases in comparison with a commercial animal coagulant (Coalhopar®).

\begin{tabular}{|c|c|c|c|c|c|}
\hline Coagulant & Sample $(\mathrm{mg}) / 500 \mathrm{~mL}$ milk & Fresh cheese $(\mathrm{g})$ & Dry cheese $^{1}(\mathrm{~g})$ & Soluble proteins ${ }^{2}(\mathrm{mg}) / \mathrm{g}$ cheese & Milk-clotting time \\
\hline \multirow{4}{*}{ C. procera } & 8 & - & - & - & $\mathrm{Nd}$ \\
\hline & 9 & $59.3 \pm 2.2^{\mathrm{a}}$ & $27.7 \pm 1.8^{\mathrm{a}}$ & $14.7 \pm 2.9^{a}$ & $17^{\prime} 05^{\prime \prime} \pm 2^{\prime}$ \\
\hline & 10 & $64.7 \pm 5.6^{\mathrm{b}}$ & $25.2 \pm 5.9^{a}$ & $15.7 \pm 2.3^{a}$ & $18^{\prime} 56^{\prime \prime} \pm 5^{\prime}$ \\
\hline & 11 & $59.1 \pm 1.1^{\mathrm{a}}$ & $24.4 \pm 3.7^{\mathrm{a}}$ & $11.7 \pm 3.6^{\mathrm{a}}$ & $10^{\prime} 53^{\prime \prime} \pm 2^{\prime}$ \\
\hline \multirow[t]{3}{*}{ C. grandiflora } & 30 & - & - & - & $\mathrm{Nd}$ \\
\hline & 40 & $53.3 \pm 2.8^{\mathrm{a}}$ & $29.2 \pm 1.7^{\mathrm{a}}$ & $14.0 \pm 3.0^{\mathrm{a}}$ & $7^{\prime} 18^{\prime \prime} \pm 30^{\prime \prime}$ \\
\hline & 50 & $51.8 \pm 4.3^{\mathrm{a}}$ & $27.8 \pm 2.6^{\mathrm{a}}$ & $12.4 \pm 7.6^{\mathrm{a}}$ & $4^{\prime} 00^{\prime \prime} \pm 50^{\prime \prime}$ \\
\hline Coalhopar® & 10 & $52.1 \pm 2.5^{\mathrm{a}}$ & $28.0 \pm 1.1^{\mathrm{a}}$ & $11.1 \pm 5.1^{\mathrm{a}}$ & $16^{\prime} 24^{\prime \prime} \pm 40^{\prime \prime}$ \\
\hline
\end{tabular}

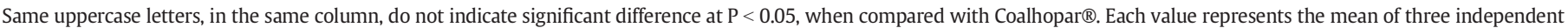
experiments and error bars indicate standard error of the mean.

Nd: non detected milk-clotting activity.

1 The fresh cheeses were freeze-dried and the dry masses were recorded.

2 Soluble proteins of the cheeses were extracted with $50 \mathrm{mM}$ Tris- $\mathrm{HCl}$ buffer (pH 6.5) and determined by Bradford (1976).

taste. Likewise, cheeses made using $C$. cardunculus flower peptidases, a traditional coagulant used in goats' cheese, demonstrated higher proteolytic activity than those made with chymosin during the ripening period (Pino, Prados, Galán, McSweeney, \& Fernández-Salguero, 2009). Therefore, the residual proteolytic activity in cheese can be listed as the main drawback of very active plant peptidases.

The residual C. procera and C. grandiflora latex proteins were not detected in cheeses made with these fractions by ELISA assays (Supplementary Fig. 5). This result can be explained because during the manufacture of the cheeses, the curds were pressed for $12 \mathrm{~h}$ to drain all whey. In this step, the latex proteins can be totally eliminated together with other soluble proteins of the whey. Previously, Ramos et al. (2006) showed that latex proteins of $C$. procera were digested by the action of digestive peptidases and they were not detected in fecal material of rats after 35 consecutive days of consumption. No death or toxic effects were observed. In another work, the same protein fraction of C. procera did not induce antibodies production when animals received latex proteins by oral route and therefore, did not develop allergy (Ramos et al., 2007). Accordingly, these results suggest that a possible toxic or allergenic reaction of cheeses produced with latex proteins of C. procera should be insignificant or null.

Other works showed the potential use of $C$. procera leaves in the manufacture of cheeses (Aworh \& Muller, 1987; Adetunji \& Salawu, 2008). In these studies, a crude juice made from $C$. procera leaves was used. The use of this total extract can be limited because it is known that latex fluids are rich sources of very toxic protein and secondary metabolites (Konno, 2011). Consequently, the quality, taste and food safety of the cheese can be very difficult to determine. Here, a purified fraction from the latex was used, which is rich in proteolytic enzymes and free of secondary metabolites and low molecular mass molecules (Freitas et al., 2007). Other works showed that cysteine peptidases from C. procera exhibited milk-clotting activity (Badgujar \& Mahajan, 2012; Oseni \& Ekperigin, 2013; Singh \& Dubey, 2011). However, their results were very preliminary. Here, we characterized the milk-clotting activity of C. procera latex peptidases which was not described before wherever such as salt effects, temperature, specific hydrolysis of k-casein by SDSPAGE, HPLC and mass spectrometry, protein autolysis, immunological detection, and residual proteolytic activity in the cheeses.

\section{Calotropis procera (CpLP)}
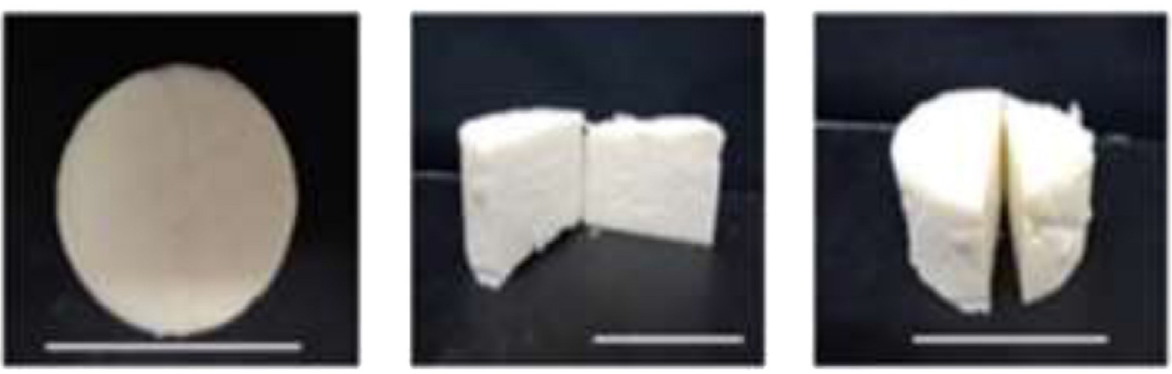

\section{Cryptostegia grandiflora (CgLP)}
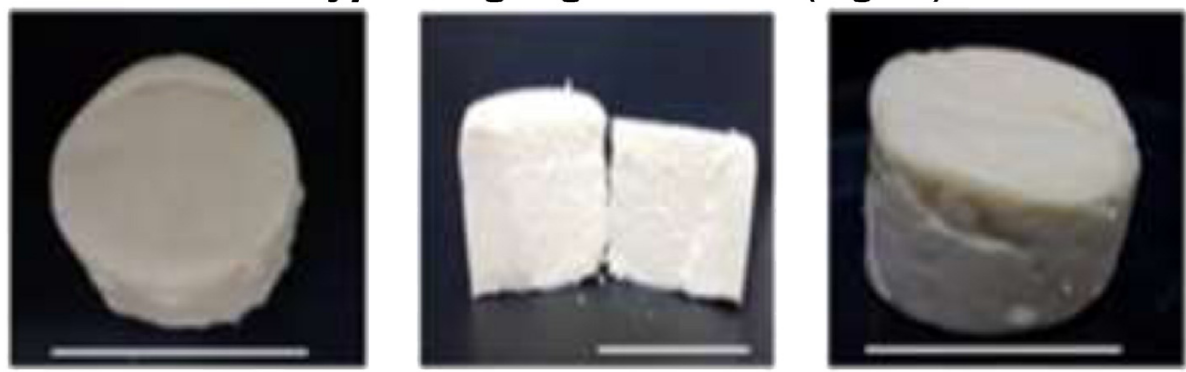

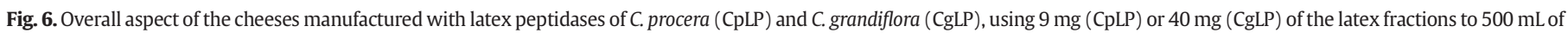
bovine milk. Bars: $5 \mathrm{~cm}$. 
C. grandiflora is a plant poorly studied. There is only two works that describes the characterization, purification and biological activity of cysteine peptidases from its latex (Freitas et al., 2010; Ramos et al., 2014). There is no study concerning the application of $C$. grandiflora peptidases in cheese manufacture.

\section{Conclusion}

It was studied the potential use of latex fractions from four plant species as milk coagulants. However, only $C$. procera and $C$. grandiflora peptidases showed potential as alternatives to the use of commercial animal chymosin. Both purified proteolytic fractions were not affected by high concentrations of $\mathrm{NaCl}$ and $\mathrm{CaCl}_{2}$, and were inactivated after heating at $75^{\circ} \mathrm{C}$ and the hydrolysis partners on $\mathrm{k}$-casein were similar to commercial chymosin. Cheeses made with $C$. procera and C. grandiflora peptidases presented a good yield, appearance, and did not present residual proteolytic activity or latex proteins.

\section{Conflict of interest}

The authors confirm that this article content has no conflicts of interest.

\section{Contributions}

CDTF, HBL, JPBO, JLA, ASE and SVC performed the main research work in this study, including latex processing, protein purification, proteolytic activity, HPLC analysis, production of polyclonal antibodies and milk-clotting assays. MDPL and ACOMM performed the analysis of casein hydrolysis by SDS-PAGE and mass spectrometry. CDTF, SVC and MVR contributed to data analyses and discussion and wrote the manuscript.

\section{Acknowledgments}

The biochemical, functional and applied studies of latex protein are supported by grants from the following Brazilian Agencies: Conselho Nacional de Desenvolvimento Científico e Tecnológico (CNPq: Universal/RENORBIO-406691/2013-4), Coordenação de Aperfeiçoamento de Pessoal de Nível Superior (CAPES-MINCYT-REDE 017/14) and Fundação Cearense de Apoio ao Desenvolvimento Científico e Tecnológico (FUNCAP). The authors thank Dr. José Tadeu Abreu de Oliveira for HPLC assays.

\section{Appendix A. Supplementary data}

Supplementary data to this article can be found online at http://dx. doi.org/10.1016/j.foodres.2016.06.020.

\section{References}

Adetunji, V. O., \& Salawu, O. T. (2008). West African soft cheese 'wara' processed with Calotropis procera and Carica papaya: A comparative assessment of nutritional values. African Journal of Biotechnology, 7, 3360-3362.

Ahmed, I. A. M., Babiker, E. E., \& Mori, N. (2010). pH stability and influence of salts on activity of a milk-clotting enzyme from Solanum dubium seeds and its enzymatic action on bovine caseins. Food Science and Technology, 43, 759-764.

Arima, K., Yu, J., \& Iwasaki, S. (1970). Milk-clotting enzyme from Mucor pusillus var Lindt. In E. G. Pearlman, \& L. lorand (Eds.), Methods in enzymology (pp. 446-459). New York: Academic Press.

Aworh, O., \& Muller, H. G. (1987). Cheese-making properties of vegetable rennet from sodom apple (Calotropis procera). Food Chemistry, 26, 71-79.

Azarkan, M., El Moussaoui, A., van Wuytswinkel, D., Dehon, G., \& Looze, Y. (2003). Fractionation and purification of the enzymes stored in the latex of Carica papaya. Journal of Chromatography B, 790, 229-238.

Badgujar, S. B., \& Mahajan, R. T. (2012). Comparison of cysteine proteases of four laticiferous plants and characterization of Euphorbia nivulia Buch-Ham. latex glycosylated cysteine peptidase. Indian Journal of Natural Products and Resources, 3, 152-160.
Badgujar, S. B., \& Mahajan, R. T. (2014). Nivulian-II a new milk clotting cysteine protease of Euphorbia nivulia latex. International Journal of Biological Macromolecules, 70, 391-398.

Bhunia, B., Basak, B., \& Dey, A. (2012). A review on production of serine alkaline protease by Bacillus spp. Journal of Biochemical Technology, 3, 448-457.

Bradford, M. M. A. (1976). A rapid and sensitive method for the quantitation of microgram quantities of protein utilizing the principle of protein-dye binding. Analytical Biochemistry, 72, 248-254.

Bruno, M. A., Lazza, C. M., Errasti, M. E., López, L. M. I., Caffini, N. O., \& Pardo, M. F. (2010). Milk clotting and proteolytic activity of an enzyme preparation from Bromelia hieronymi fruits. Food Science and Technology, 43, 695-701.

Chen, X. L., Shun, C. Y., Zhang, Y. Z., \& Gao, P. J. (2003). Rapid monitoring of autolysis process of proteases by capillary electrophoresis. Biotechnology Letters, 25, 1763-1767.

Domsalla, A., \& Melzing, M. F. (2008). Occurrence and properties of proteases in plant latices. Planta Medica, 74, 699-711.

Dubey, V. K., \& Jagannadham, M. V. (2003). Procerain, a stable cysteine protease from the latex of Calotropis procera. Phytochemistry, 62, 1057-1071

Egito, A. S., Girardet, J. M., Laguna, L. E., Poirson, C., Molle, D., Miclo, L., et al. (2007). Milk clotting activity of enzyme extracts from sunflower and albizia seeds and specific hydrolysis of bovine k-casein. International Dairy Journal, 17, 816-825.

Esteves, C. L. C., Lucey, J. A., Hyslop, D. B., \& Pires, E. M. V. (2003). Effect of gelation temperature on the properties of skim milk gels made from plant coagulants and chymosin. International Dairy Journal, 13, 877-885.

Famelart, M. H., Le Graet, Y., \& Raulot, K. (1999). Casein micelle dispersions into water, $\mathrm{NaCl}$ and $\mathrm{CaCl}_{2}$ : Physicochemical characteristics of micelles and rennet coagulation. International Dairy Journal, 9, 293-297.

Freitas, C. D. T., Cruz, W. T., Silva, M. Z. R., Vasconcelos, I. M., Moreno, F. B. M. B., Moreira, R. A., et al. (2016). Proteomic analysis and purification of an unusual germin-like protein with proteolytic activity in the latex of Thevetia peruviana. Planta, 243, 1115-1128.

Freitas, C. D. T., Oliveira, J. S., Miranda, M. R. A., Macedo, N. M. R., Sales, M. P., Villas-Boas, L. A., et al. (2007). Enzymatic activities and protein profile of latex from Calotropis procera. Plant Physiology and Biochemistry, 45, 781-789.

Freitas, C. D. T., Silva, M. Z. R., Bruno-Moreno, F., Monteiro-Moreira, A. C. O., Moreira, R. A., \& Ramos, M. V. (2015). New constitutive latex osmotin-like proteins lacking antifungal activity. Plant Physiology and Biochemistry, 96, 45-52.

Freitas, C. D. T., Souza, D. P., Araújo, E. S., Cavalheiro, M. G., Oliveira, L. S., \& Ramos, M. V. (2010). Anti-oxidative and proteolytic activities and protein profile of laticifer cells of Cryptostegia grandiflora, Plumeria rubra and Euphorbia tirucalli. Brazilian Journal of Plant Physiology, 22, 11-22.

González-Rábade, N., Badillo-Corona, J. A., Aranda-Barradas, J. S., \& Oliver-Salvador, M. C. (2011). Production of plant proteases in vivo and in vitro - A review. Biotechnology Advances, 29, 983-996.

Grozdanovic, M. M., Burazer, L., \& Gavrovic-Jankulovic, M. (2013). Kiwifruit (Actinidia deliciosa) extract shows potential as a low-cost and efficient milk-clotting agent. International Dairy Journal, 32, 46-52.

Guiama, V. D., Libouga, D. G., Ngah, E., Beka, R. G., Ndi, K. C., Maloga, B., et al. (2010). Milkclotting potential of fruit extracts from Solanum esculentum, Solanum macrocarpon and Solanum melongena. African Journal of Biotechnology, 9, 1797-1802.

Guinee, T. P., \& Fox, P. F. (2004). Salt in cheese: Physical, chemical and biological aspects In P. F. Fox (Ed.), Cheese: Chemistry, physics and microbiology ( $3^{\text {rd }}$ ed.). General aspects, vol 1., . London, UK: Chapman and Hall.

Hang, F., Wang, Q., Hong, Q., Liu, P., Wu, Z., Liu, Z., et al. (2016). Purification and characterization of a novel milk-clotting metalloproteinase from Paenibacillus spp. BD3526. International Journal of Biological Macromolecules, 85, 547-554.

Hashim, M. M., Mingsheng, D., Iqbal, M. F., \& Xiaohong, C. (2011). Ginger rhizome as a potential source of milk coagulating cysteine protease. Phytochemistry, 72, 458-464.

Huang, X. W., Chen, L. J., Luo, Y. B., Guo, H. Y., \& Ren, F. Z. (2011). Purification, characterization, and milk coagulating properties of ginger proteases. Journal of Dairy Science, 94, 2259-2269.

Jacob, M., Jaros, D., \& Rohm, H. (2011). Recent advances in milk clotting enzymes. International Journal of Dairy Technology, 64, 14-33.

Konno, K. (2011). Plant latex and other exudates as plant defense systems: Roles of various defense chemicals and proteins contained therein. Phytochemistry, 72, 1510-1530.

Konno, K., Hirayama, C., Nakamura, M., Tateishi, K., Tamura, Y., Hattori, M., et al. (2004). Papain protects papaya trees from herbivorous insects: Role of cysteine proteases in latex. Plant Journal, 37, 370-378.

Kumari, M., Sharma, A., \& Jagannadham, M. V. (2012). Religiosin B, a milk-clotting serine protease from Ficus religiosa. Food Chemistry, 131, 1295-1303.

Laemmli, U. K. (1970). Cleavage of structural proteins during the assembly of the head of bacteriophage T4. Nature, 227, 680-685.

Lewinsohn, T. M. (1991). The geographical distribution of plant latex. Chemoecology, 2 64-68.

Llorente, B. E., Obregón, W. D., Avilés, F. X., Caffini, N. O., \& Vairo-Cavalli, S. (2014). Use of artichoke (Cynara scolymus) flower extract as a substitute for bovine rennet in the manufacture of Gouda-type cheese: Characterization of aspartic proteases. Food Chemistry, 159, 55-63.

Naz, S., Masud, T., \& Nawaz, M. A. (2009). Characterization of milk coagulating properties from the extract of Withania coagulans. International Journal of Dairy Technology, 62, 315-320.

Ningthoujam, D. S., Kshetri, P., Sanasam, S., \& Nimaichand, S. (2009). Screening, identification of best producers and optimization of extracellular proteases from moderately halophilic alkali thermotolerant indigenous Actinomycetes. World Applied Sciences Journal, 7, 907-916.

Oseni, O. A., \& Ekperigin, M. M. (2013). Partial characterization of proteolytic and milk clotting enzymes in sodom apple Calotropis procera (Ait.) R.Br. (Asclepiadaceae) plant. American Journal of Biochemistry and Molecular Biology, 3, 256-263. 
Pino, A., Prados, F., Galán, E., McSweeney, P. L. H., \& Fernández-Salguero, J. (2009). Proteolysis during the ripening of goats' milk cheese made with plant coagulant or calf rennet. Food Research International, 42, 324-330.

Pontual, E. V., Carvalho, B. E. A., Bezerra, R. S., Coelho, L. C. B. B., Napoleão, T. H., \& Paiva, P. M. G. (2012). Caseinolytic and milk-clotting activities from Moringa oleifera flowers. Food Chemistry, 135, 1848-1854.

Ramos, M. V., Aguiar, V. C., Melo, V. M. M., Mesquita, R. O., Silvestre, P. P., Oliveira, J. S., et al. (2007). Immunological and allergenic responses induced by latex fractions of Calotropis procera (Ait.) R.Br. Journal of Ethnopharmacology, 111, 115-122.

Ramos, M. V., Aguiar, V. C., Xavier, A. A. S., Lima, M. W., Bandeira, G. P., Etchells, J. P., et al (2006). Latex proteins from the plant Calotropis procera are partially digested upon in vitro enzymatic action and are not immunologically detected in fecal material. Fitoterapia, 77, 251-256.

Ramos, M. V., Araújo, E. S., Jucá, T. L., Monteiro-Moreira, A. C. O., Vasconcelos, I. M. Moreira, et al. (2013). New insights into the complex mixture of latex cysteine peptidases in Calotropis procera. International Journal of Biological Macromolecules, 58, 211-219.

Ramos, M. V., Souza, D. P., Gomes, M. T. R., Freitas, C. D. T., Carvalho, C. P. S., Júnior, P. A. V. R., et al. (2014). A phytopathogenic cysteine peptidase from latex of wild rubber vine Cryptostegia grandiflora. Protein Journal, 33, 199-209.

Rawdkuen, S., Jaimakreu, M., \& Benjakul, S. (2013). Physicochemical properties and tenderness of meat samples using proteolytic extract from Calotropis procera latex. Food Chemistry, 136, 909-916.

Rezanejad, H., Karbalaei-Heidari, H. R., Rezaei, S., \& Yousefi, R. (2015). Microsciadin, a new milk-clotting cysteine protease from an endemic species, Euphorbia microsciadia. Biomacromolecular Journal, 1, 93-103.

Salas, C. E., Gomes, M. T. R., Hernandez, M., \& Lopes, M. T. P. (2008). Plant cysteine proteinases: Evaluation of the pharmacological activity. Phytochemistry, 69, 2263-2269.
Shah, M. A., Mir, S. A., \& Paray, M. A. (2014). Plant proteases as milk-clotting enzymes in cheese making: A review. Dairy Science \& Technology, 94, 5-16.

Silva, S. V., \& Malcata, F. X. (2005). Studies pertaining to coagulant and proteolytic activities of plant proteases from Cynara cardunculus. Food Chemistry, 89, 19-26.

Singh, A. N., \& Dubey, V. K. (2011). Exploring applications of procerain b, a novel protease from Calotropis procera, and characterization by $\mathrm{N}$-terminal sequencing as well as peptide mass fingerprinting. Applied Biochemistry and Biotechnology, 164, 573-580.

Sumner I. G, Harris, G. W. Taylor, M. A J Pickersgill, R. W Owen, A J \& Goodenough, P. W. (1993). Factors effecting the thermostability of cysteine proteinases from Carica papaya. European Journal of Biochemistry, 214, 129-134.

Tavano, O. L. (2013). Protein hydrolysis using proteases: An important tool for food biotechnology. Journal of Molecular Catalysis B: Enzymatic, 90, 1-11.

Teixeira, R. D., Ribeiro, H. A. L., Gomes, M. T., Lopes, M. T. P., \& Salas, C. E. (2008). The proteolytic activities in latex from Carica candamarcensis. Plant Physiology and Biochemistry, 46, 956-961.

Torres, M. J., Trejo, S. A., Martin, M. I., Natalucci, C. L., Avilés, F. X., \& López, L. M. I. (2010). Purification and characterization of a cysteine endopeptidase from Vasconcellea quercifolia A. St.-Hil. Latex displaying high substrate specificity. Journal of Agricultural and Food Chemistry, 58, 11027-11035.

Viana, C. A., Oliveira, J. S., Freitas, C. D. T., Alencar, N. M. N., Carvalho, C. P. S., Nishi, B. C., et al. (2013). Thrombin and plasmin-like activities in the latices of Cryptostegia grandiflora and Plumeria rubra. Blood Coagulation E Fibrinolysis, 24, 386-392.

Wolfschoon-Pombo, A. F. (1997). Influence of calcium chloride addition to milk on the cheese yield. International Dairy Journal, 7, 249-254.

Zare, H., Moosavi-Movahedi, A. A., Salami, M., Mirzaei, M., Saboury, A. A., \& Sheibani, N. (2013). Purification and autolysis of the ficin isoforms from fig (Ficus carica cv. Sabz) latex. Phytochemistry, 87, 16-22. 